\title{
MOSTY NAD PRZEPAŚCIĄ? W ODPOWIEDZI MICHAŁOWI PIEKARSKIEMU
}

\begin{abstract}
Streszczenie. Artykuł jest dyskusją z wybranymi elementami interpretacji pracy Witolda Płotki pt. Studia z fenomenologii poznania. Transcendentalna filozofia Edmunda Husserla a problem wiedzy, którą sformułował Michał Piekarski. W artykule pyta się o relację metody fenomenologicznej do szeroko pojętego postępowania analitycznego, wskazując na podobieństwa i różnice pomiędzy oboma podejściami. Ponadto autor przybliża rozumienie języka przez Husserla, zwłaszcza w kontekście analizy noematu.
\end{abstract}

Słowa kluczowe: filozofia języka, fenomenologia, noemat, Edmund Husserl, Roman Ingarden

Artykuł polemiczny autorstwa Michała Piekarskiego, poświęcony książce mojego autorstwa pt. Studia z fenomenologii poznania. Transcendentalna filozofia Edmunda Husserla a problem wiedzy, porusza szereg kwestii związanych z zarysowaną w tej pracy ideą fenomenologii poznania jako ejdetyczno-transcendentalnego sposobu analizy relacji poznawczej. Polemika skupia się na pytaniu o rolę języka w poznaniu. W odpowiedzi na to omówienie zwrócę uwagę na związki fenomenologii z metodą analizy językowej i, szerzej, na możliwe sposoby rozwinięcia problemów poruszanych przez Piekarskiego. W tym kontekście będę dyskutował z możliwością fenomenologicznego uzasadnienia implikacji materialnej, która ma towarzyszyć każdemu aktowi poznania, oraz pokrótce rozważę rozumienie języka w fenomenologii. Chociaż recenzent porusza różne zagadnienia związane z problemem języka, koniec końców polemika ta pozwala na postawienie kwestii fundamentalnej, a dokładniej problemu rozumienia metody fenomenologicznej jako takiej. 
Zdaniem Piekarskiego, „klasyczna fenomenologia problem języka pozostawiła na antypodach swoich rozważań" 1 . Zarzut ten, chociaż zbyt radykalny, po części wydaje się trafny. Wypływa on z kwestii ogólniejszej. Fenomenologię często redukuje się do hasła „powrotu do rzeczy samych", zapominając jednocześnie, że w punkcie wyjścia fenomenolog powinien porzucić „same tylko słowa”. Słowa, a szerzej także język, zdają się być niczym istotnym - przynajmniej dla Husserla - bez ich intuicyjnego wypełnienia. Można argumentować, $\dot{z}$ e w tej perspektywie ważniejsza od języka jest intuicja, chociaż paradoksalnie - co należy wyraźnie podkreślić - bez języka nie ma analizy fenomenologicznej, która bądź co bądź realizuje się w opisach tego, co się prezentuje, i umożliwia odniesienie się do istoty danego w doświadczeniu fenomenu. Owo zapomnienie, czy raczej porzucenie języka w fenomenologii pokutuje, jak sądzi Piekarski, do dzisiaj. W Polsce stało się ono powodem dla ujęcia fenomenologii jako filozofii naiwnej, bo niezdającej relacji z uwikłania w język, przez co wydaje się podążać jedynie za intuicjami języka potocznego ${ }^{3}$. Piekarski zdaje się zakładać trafność tej krytyki, pokazując, że głównym oponentem fenomenologii jest anglosaska filozofia analityczna. Pytanie o relację metody fenomenologicznej do analitycznej na pewno nie jest nowe ${ }^{4}$, ale tekst Piekarskiego, w którym autor domaga się

1 M. Piekarski, Podstawy fenomenologii poznania a problem języka. Polemika z Witoldem Płotka, Studia Philosophiae Christianae 55(2019)4, ????.

2 E. Husserl, Badania logiczne. Tom II. Badania dotyczące fenomenologii i teorii poznania. Część I, przeł., wstępem poprzedził i przypisami opatrzył J. Sidorek, przekład przejrzał A. Półtawski, Warszawa 2000, 9.

3 Zob. np. A. Gawroński, Zmierzch formacji kartezjańskiej, Więź (1979)6, 33-51; tenże, Zmierzch formacji kartezjańskiej (II), Więź (1980)1, 30-44. Zob. także tenże, Dlaczego Platon wykluczył poetów z Państwa? U źródeł współczesnych badań nad językiem, Warszawa 1984, 251-325.

4 Zob. np. D. Ihde, Some Parallels Between Analysis and Phenomenology, Philosophy and Phenomenological Research 27(1967)4, 577-586 oraz G. Lock, Some Comments on Analytic Philosophy and Phenomenology, w: Logos of Phenomenology and Phenomenology of the Logos. Book I: Phenomenology as the Critique of Reason in Contemporary Criticism and Interpretation, red. A.-T. Tymieniecka, Dordrecht 2005, 49-61. Ostatnio tym 
swoistych linguistic i pragmatic turn $\mathrm{w}$ fenomenologii, skłania do ponownego jego przemyślenia.

Przede wszystkim należy podkreślić, że oba podejścia - fenomenologiczne i analityczne - różnią się, jak podkreślam to w książce ${ }^{5}$ odmiennymi przedmiotami i metodami postępowania. Piekarski często jednak pomija tę różnicę, twierdząc, że rozwój fenomenologii polega na „nowym zdefiniowaniu” terminów, które pochodzą z tradycji ${ }^{6}$. Odnosi się przy tym do fragmentu Idei I, w którym Husserl ujmuje istotę jako "nowego rodzaju przedmiot” indywidualny ${ }^{7}$. Trafniejszym przykładem jest zapewne fragment Wprowadzenia do Idei I, gdzie Husserl wprost pisze o potrzebie „zmiany terminologii” Badań logicznych ${ }^{8}$. Tym, co proponuje Husserl, nie jest jednak prosta zamiana jednego terminu przez drugi. Tym bardziej nie chodzi o nowe definicje terminów. Jednym słowem, celem fenomenologii nie jest, jak sugeruje to Piekarski, ukucie nowych definicji. Pisząc o potrzebie wyjścia poza tradycyjną terminologię, Husserl odnosi się raczej do paradoksalnego statusu fenomenologii, która powinna myśleć „poza” językiem tradycji (jedynie ze względu na „rzeczy same”), ale jednocześnie nie dysponuje żadnym właściwym sobie słownikiem. Stąd fenomenologia, będąc filozofią początku, która stawia radykalnie nowe

zagadnieniem zajmował się Uwe Meixner; zob. tegoż Defending Husserl. A Plea in the Case of Wittgenstein \& Company versus Phenomenology, Berlin 2014. W Polsce przykładem tej dyskusji jest polemika z interpretacją Jana Czerniawskiego, którą na łamach Filozofii Nauki podjęli Jan Woleński i Józef Dębowski. Zob. J. Woleński, Czy filozof analityczny potrzebuje epistemicznej viagry?, Filozofia Nauki 29(2000)1, 99-104; J. Czerniawski, Filozofia analityczna a metoda fenomenologiczna, Filozofia Nauki 31-32(2000)3-4, 133-138 oraz J. Dębowski, Pomiędzy epistemiczną impotencją a epistemiczną omnipotencją, Filozofia Nauki 31-32(2000)3-4, 139-145.

5 W. Płotka, Studia z fenomenologii poznania. Transcendentalna filozofia Edmunda Husserla a problem wiedzy, Gdańsk 2015, 21.

6 Zob. M. Piekarski, art. cyt., 5.

7 Zob. E. Husserl, Idee czystej fenomenologii i fenomenologicznej filozofii, przeł. i przypisami opatrzyła D. Gierulanka, tłumaczenie przejrzał i wstępem poprzedził R. Ingarden, Warszawa 1967, 22.

8 Zob. tamże, 12. 
pytania, a jednocześnie pretenduje do bycia filozofią rygorystyczną, nie może dostatecznie jasno wypowiedzieć swych własnych podstaw teoretycznych i metodologicznych. Problem ten był przedmiotem innych opracowań i nie jest tutaj rozstrzygający9. Ważniejsze jest podkreślenie, że język nie jest dla fenomenologa przeźroczystym medium, które nie modyfikuje badanego przedmiotu. Wręcz przeciwnie. Język jest wciąż obecnym elementem, który współkonstytuuje przedmiot. Dlatego postulat opisu, który miałby korzystać z „Zasady wszelkich zasad", jest raczej ideą regulatywną i wyraża dążenie do eliminacji możliwie dużej liczby określeń narzucanych jedynie przez relacje właściwe danemu językowi. Uważam, że dokładnie w tym kontekście należy odczytywać fragment z $U$ podstaw teorii poznania Ingardena, na który powołuje się także Piekarski ${ }^{10}$, a w którym mówi się o „unikaniu wszelkich hipotez lub założeń czysto pojęciowych"11. A zatem nie definiowanie, lecz opis jest właściwą płaszczyzną realizacji metody fenomenologicznej, przy czym opis jest otwarty na korekty.

W odpowiedzi na zarzuty Piekarskiego, chciałbym zaproponować złagodzenie niektórych jego tez, inne zaś uznać za problematyczne. Jak sądzę, nie jest tak, że uwzględnienie zagadnienia języka pozwoli nam na przekroczenie naiwności klasycznej fenomenologii ku krytycznej refleksji nad językiem. Dlatego - wbrew tezie o absolutyzowaniu języka - w książce przyjąłem, że język koresponduje z momentem pełnego noematu, który opisałem jako moment kategorialny ${ }^{12}$. Wypowiedzi językowe korespondują z tym momentem i go wyrażaja. Proponuję zatem, aby język traktować holistycznie jako element relacji poznawczej, ale na pewno nie jako element dominujący, czy

9 Zob. N. de Warren, Wezwanie Husserla do mówienia: fenomenologia „filozofia mniejszą", w: Wprowadzenie do fenomenologii. Interpretacje, zastosowania, problemy. Tom I, red. W. Płotka, Warszawa 2014, 50-77.

10 Zob. M. Piekarski, art. cyt., 4-5.

11 R. Ingarden, U podstaw teorii poznania. Część pierwsza, Warszawa 1971, 233.

12 Zob. W. Płotka, dz. cyt., 185. 
wręcz jedyny. Wątpię także, by - jak chce tego Piekarski ${ }^{13}$ - każdemu przeżyciu towarzyszyła forma rozumowania, którą ujmuje się - za Brandomem - jako inferencję materialną. Uważam, że tego rodzaju konstrukcja nie jest konieczna, lecz raczej sztuczna, jak na przykład w przypadku aktu słuchania II Symfonii Góreckiego Kopernikowskiej; akt ten może być przecież czysto pasywnym przeżywaniem, któremu nie towarzyszą jakiekolwiek rozumowania. Wydaje się, że propozycja Piekarskiego zaciera fenomenologiczne bogactwo przeżyć i złożoną strukturę innych momentów pełnego noematu; w każdym razie noemat konstytuuje się jako całość tworzących go momentów.

Od strony semantycznej można zatem powiedzieć, że wypowiedź odnosi się do stanu rzeczy, ale przedmiotem aktu poznania są pełne noematy. W związku z tym, jak dowodzi Piekarski, w mojej książce można znaleźć „statyczną” koncepcję języka, „według której znaczenia są względnie stabilne, a kolejne zdania uzyskuje się albo na bazie nowych doświadczeń, albo na podstawie dedukcji" ${ }^{14}$. Uważam, że zarzut ten jest nietrafiony. Referencyjna teoria znaczenia, która jest obecna w klasycznej fenomenologii, nie wyczerpuje przecież rozumienia języka przez Husserla, który z czasem rozbudował proponowane przez siebie ujęcie języka w ten sposób, że ostatecznie rozumiał go jako fenomen świata życia, który współkonstytuuje się w relacji środowiska, podmiotu i całej wspólnoty komunikacyjnej ${ }^{15}$. W swojej książce aspekt ten oddaję w teorii „otwartej” intencjonalności, której funkcja polega na prezentowaniu przedmiotu usytuowanego w danych horyzontach. „Otwartośc” relacji poznawczej wskazuje, jak się wydaje, na możliwość ujęcia języka jako fenomenu pragmatycznego, który jest zakorzeniony nie tylko w danej sytuacji, lecz ponadto także w tradycji, wspólnocie komunikacyjnej oraz w danym

13 Zob. M. Piekarski, art. cyt., 5.

14 Tamże, 7.

15 Na ten temat zob. np. D. Zahavi, Husserl und die transzendentale Intersubjektivität. Eine Antwort auf die sprachpragmatische Kritik, Dordrecht 1996 oraz S. D. Kelly, The Relevance of Phenomenology to the Philosophy of Language and Mind, New York-London 2001. 
sposobie posługiwania się językiem. Na końcu dodam jedynie, że w Studiach nie poruszam w dostatecznym stopniu problemów funkcji języka w poznaniu i szerzej - fenomenologii języka jako fenomenu pragmatycznego; uważam jednak, że takie opracowanie wymaga osobnych, dogłębnych badań, i z tego powodu kierunek wskazany przez Piekarskiego wydaje się interesującym kierunkiem rozwoju fenomenologii poznania. Przypuszczam, że realizując ten postulat, można wprowadzić fenomenologię i filozofię analityczną w owocny dialog, co byłoby zarazem metaforycznym mostem na przepaścią pomiędzy oboma działami filozofii.

Podsumowując moją odpowiedź, zaznaczę, że w Studiach bronię stanowiska fundacjonalizmu umiarkowanego, które wyraża się w tezie, że oczywistość nie jest niezawodna, lecz raczej z istoty korygowalna. Mówiąc wprost, opisy fenomenologiczne oraz tworzone na ich podstawie teorie są otwarte na dyskusje i dalsze korekty. Nauką, która plynie $\mathrm{z}$ tak rozumianej fenomenologii poznania, jest prosta obserwacja, że nie ma żadnego „widoku znikąd”, który przekracza wszelkie horyzonty i ograniczenia poznawcze. Obserwację tę w jakimś stopniu potwierdza dyskutowana przeze mnie polemika. Bądź co bądź Piekarski pokazuje, że poznanie nie jest zamknięte na korekty oraz dalsze możliwe kierunki rozwoju. W książce utrzymuję, że normą postępowania w poznaniu jest prawda. Sądzę, że dyskutowalność rezultatów analizy fenomenologicznej oraz ich istotowa korygowalność pozwalają budować mosty nad przepaścią pomiędzy różnymi propozycjami opisu. Ufam, że w swojej odpowiedzi na zarzuty i wątpliwości sformułowane w polemice, która wciąż ma charakter raczej przyczynku do dyskusji, udało mi się zbudować chociaż kilka takich mostów, a przez to - skorygować przynajmniej niektóre z licznych niedociągnięć mojej książki, przede wszystkim jednak udało się pełniej określić zakres, przedmiot i metody fenomenologii poznania. 


\section{BILBIOGRAFIA}

Czerniawski J., Filozofia analityczna a metoda fenomenologiczna, Filozofia Nauki 31-32(2000)3-4, 133-138.

De Warren N., Wezwanie Husserla do mówienia: fenomenologia "filozofia mniejsza", w: Wprowadzenie do fenomenologii. Interpretacje, zastosowania, problemy. Tom I, red. W. Płotka, Warszawa 2014, 50-77.

Dębowski J., Pomiędzy epistemiczna impotencją a epistemicznq omnipotencja, Filozofia Nauki 31-32(2000)3-4, 139-145.

Gawroński A., Zmierzch formacji kartezjańskiej, Więź (1979)6, 33-51.

Gawroński A., Zmierzch formacji kartezjańskiej (II), Więź (1980)1, 30-44.

Gawroński A., Dlaczego Platon wykluczyt poetów z Państwa? Uźródet wspótczesnych badań nad językiem, Warszawa 1984.

Husserl E., Badania logiczne. Tom II. Badania dotyczqce fenomenologii i teorii poznania. Częś́ I, przeł., wstępem poprzedził i przypisami opatrzył J. Sidorek, przekład przejrzał A. Półtawski, Warszawa 2000.

Husserl E., Idee czystej fenomenologii i fenomenologicznej filozofi, przeł. i przypisami opatrzyła D. Gierulanka, tłumaczenie przejrzał i wstępem poprzedził R. Ingarden, Warszawa 1967.

Ihde D., Some Parallels Between Analysis and Phenomenology, Philosophy and Phenomenological Research 27(1967)4, 577-586.

Ingarden R., U podstaw teorii poznania. Czesśc pierwsza, Warszawa 1971.

Kelly S.D., The Relevance of Phenomenology to the Philosophy of Language and Mind, New York-London 2001.

Lock G., Some Comments on Analytic Philosophy and Phenomenology, w: Logos of Phenomenology and Phenomenology of the Logos. Book I: Phenomenology as the Critique of Reason in Contemporary Criticism and Interpretation, red. A.-T. Tymieniecka, Dordrecht 2005, 49-61.

Meixner U., Defending Husserl. A Plea in the Case of Wittgenstein \& Company versus Phenomenology, Berlin 2014.

Piekarski M., Podstawy fenomenologii poznania a problem jezzyka. Polemika z Witoldem Ptotka, Studia Philosophiae Christianae 55(2019)4, 137-149.

Płotka W., Studia z fenomenologii poznania. Transcendentalna filozofia Edmunda Husserla a problem wiedzy, Gdańsk 2015.

Woleński J., Czy filozof analityczny potrzebuje epistemicznej viagry?, Filozofia Nauki 29(2000)1, 99-104.

Zahavi D., Husserl und die transzendentale Intersubjektivität. Eine Antwort auf die sprachpragmatische Kritik, Dordrecht 1996. 


\section{BRIDGES OVER THE GAPS? A RESPONSE TO MICHAŁ PIEKARSKI}

Abstract. This article discusses certain aspects of Michał Piekarski's analysis of Witold Płotka's book Studies in the Phenomenology of Cognition. The transcendental Philosophy of Edmund Husserl and the Problem of Knowledge. It considers the relationship between the phenomenological method and the analytical approach broadly understood. It also examines the similarities and differences between the two approaches. Lastly, the author reconstructs Husserl's view of language, especially in the context of the analysis of the noema.

Keywords: philosophy of language, phenomenology, noema, Edmund Husserl, Roman Ingarden

Witold Płotka

w.plotka@uksw.edu.pl

Uniwersytet Kardynała Stefana Wyszyńskiego w Warszawie, Instytut Filozofii

Wóycickiego 1/3, 01-938 Warszawa

DOI: 10.21697/spch.2019.55.4.07 